\title{
A clue to the Asian origin of euprimates
}

\author{
XIJUN NI ${ }^{1 *}$, YAOMING HU ${ }^{1,2,3}$, YUANQING WANG ${ }^{1}$, CHUANKUI LI $^{1}$ \\ ${ }^{1}$ Institute of Vertebrate Paleontology and Paleoanthropology, Chinese Academy of Sciences, Beijing 100044, China \\ ${ }^{2}$ American Museum of Natural History, New York, New York 10024, USA \\ ${ }^{3}$ Biology Program (Ecology, Evolutionary Biology, and Behavior), Graduate School and City College, \\ City University of New York, New York 10016, USA
}

Received 30 June 2003; accepted 24 February 2004

\begin{abstract}
Competing hypotheses maintain that euprimates originated in Africa, the Indian subcontinent, or East Asia, although the earliest unequivocally identified euprimates have been recorded mainly from Europe and North America. Recently we reported the discovery of Teilhardina asiatica from the earliest Eocene of China. This discovery constitutes the oldest unambiguous euprimate from Asia, and represents the most primitive known omomyid. It suggests that European and North American omomyids were probably rooted in Asia, and casts new light on the Asian-origin hypothesis of euprimates. The possibility of finding morphologically more generalized euprimates (or proto-euprimates) in southern China cannot be dismissed.
\end{abstract}

Key words: Teilhardina, euprimate, omomyid, Asian origin

\section{Introduction}

Euprimates, or 'primates of modern aspect' (Simons, 1972; Hoffstetter, 1977; Szalay and Delson, 1979), is now widely accepted as a monophyletic group (Szalay and Delson, 1979; Kay et al., 1997; Fleagle, 1999). It includes extant lemurs, lorises, tarsiers, anthropoids, and their close fossil relatives. The phylogenetic and geographic origins of euprimates are unknown and are the subject of interest and debate. We recently reported the discovery of Teilhardina asiatica from the earliest Eocene of China (Ni et al., 2004). This discovery constitutes the oldest unambiguous euprimate from Asia, and represents the most primitive known omomyid. The phylogenetic position, morphological characteristics, and inferred dietary habit and activity pattern of T. asiatica were described in Ni et al. (2004). However the impact of the new discovery on the zoogeographic origin and early evolution of euprimates has not been sufficiently discussed.

\section{The Earliest Euprimates}

Purported omomyids from periods preceding the Eocene include Decoredon anhuiensis and Altiatlasius koulchii. D. anhuiensis is a recombination of "Diacronus" anhuiensis Xu 1976 and Decoredon elongatus Xu 1977, which were originally described as an anagalid and a hyopsodontid, respectively. Both derive from the middle Paleocene of southern China. D. anhuiensis was proposed as the oldest omomyid (Szalay and Li, 1986), but this suggestion has now been gen-

* Corresponding author. e-mail: ni xj@263.net phone: +86-10-68935270; fax: +86-10-68935270

Published online 11 August 2004

in J-STAGE (www.jstage.jst.go.jp) DOI: 10.1537/ase.04S001 erally rejected (Sigé et al., 1990; Rose et al., 1994; Rose, 1995). A more widely accepted Paleocene example of a euprimate is $A$. koulchii, which was described on the basis of a few isolated teeth from the late Paleocene of Morocco (Gingerich, 1990; Sigé et al., 1990). It was allocated to Omomyidae (Sigé et al., 1990), and even considered potentially related to anthropoids (Sigé et al., 1990; Godinot, 1994). Rose et al. (1994), however, argued that it is difficult to be certain whether this taxon is a euprimate, and if it is, that it is also difficult to distinguish between primitive omomyids and adapiforms based on the few isolated teeth. They concluded that the phylogenetic position of the species could not be precisely determined without more complete fossil specimens. As Sigé et al. (1990) noted in the original description of $A$. koulchii, this species shares some dental characters with plesiadapiforms such as Berruvius, Micromomys, and Tinimomys. A. koulchii possesses a very broad buccal cingulum and a well-developed anterolaterally expanded parastyle on its upper molar, and a cliff-like lingual wall in the lower premolars. These characteristics are uncommon among euprimates, but distinctive in many plesiadapiforms. Hooker et al. (1999) allocated Altiatlasius to Toliapinidae, a family of Plesiadapiformes, together with Toliapina, Berruvius, Avenius, and Sarnacius. Whether the species represents an offshoot of Plesiadapiformes or an early split branch of Euprimates is still an open question. Another debated species, Altanius orlovi from the early Eocene Bumban Member of the Naran Bulak Formation, Mongolia, is dentally more omomyid-like. This species is considered either as the earliest omomyid from Asia (Dashzeveg and McKenna, 1977; Szalay and Li, 1986), or a basal euprimate lying outside of the early euprimate clade, which includes Cantius and Teilhardina (Gingerich et al., 1991; Beard and Wang, 1995). An alternative hypothesis argues that $A$. orlovi is a plesiadapiform rather than a eupri- 
mate (Rose and Krause, 1984; Godinot, 1994; Rose et al., 1994; Rose, 1995). Our recent cladistic analysis (Ni et al., 2004) indicates that $A$. orlovi does not form a monophyletic group with euprimates, and instead is part of the plesiadapiform clade.

The earliest unequivocally identified euprimates, which share key anatomical features with living primates, are from the early Eocene, about 55 million years ago (Rose et al., 1994; Rose, 1995; Fleagle, 1999). Even at their earliest appearance, these primates can be allocated to two groups, the lemur-like Adapiformes and tarsier-like Omomyiformes (or Omomyidae) (Szalay and Delson, 1979; Rose et al., 1994; Fleagle, 1999). The earliest of the former is Cantius torresi from the basal Wasatchian of North America reported by Gingerich (1986). Anatomically the most primitive adapiform is Donrussellia from the early Sparnacian of West Europe (Godinot, 1978, 1981; Godinot et al., 1987; Rose et al., 1994). Teilhardina belgica from Europe is generally accepted as the earliest and most primitive omomyid. It is one of the most generalized omomyid and is considered to be very near the base of the first euprimate radiation. The type species of Teilhardina, T. belgica, was first allied to Omomys by Teilhard de Chardin (1927), and then placed in a new genus Teilhardina (Simpson, 1940). The species is recorded from basal Sparnacian deposits (earliest early Eocene) of Belgium and France (Teilhard de Chardin, 1927; Russell et al., 1967), and it is the only known species of the genus in Europe.

Bown (1976) extended the geographic range of the genus to North America when he described "Teilhardina" americana, a species from the lower Willwood Formation of Wyoming (early Wasatchian bed, early Eocene in age). "Teilhardina" americana resembles the European species but with a few derived features. Further discoveries and well-documented specimens indicate that the North American "Teilhardina" is more diversified than Teilhardina in Europe (Bown and Rose, 1987; Gingerich, 1993; Rose, 1995).

In Asia, evidence for early euprimates is rather limited. The recent discovery of $T$. asiatica from China expands the distribution of the genus into Asia (Ni et al., 2004). T. asiatica is the earliest unequivocally identified euprimate known from Asia.

\section{Teilhardina asiatica from China}

T. asiatica was discovered from the upper section of the Lingcha Formation in Hengyang Basin, Hunan Province, China. The mammalian faunal assemblage from this locality has been correlated with the Bumbanian of the Asian land mammal ages, based on the co-occurrence of Orientolophus, Propachynolophus, Cocomys, and also with the Wasatchian of North America and the Sparnacian of Europe (Russell and Zhai, 1987; Ting, 1993). Recent advances in isotopic stratigraphy, magnetostratigraphy, and quantitative biochronology revealed that the upper part of the Lingcha Formation is just at the Paleocene/Eocene boundary with an estimated age of $55.0 \mathrm{Ma}$ (Bowen et al., 2002). The specimens of T. asiatica include a partially preserved skull and associated lower jaws, an isolated lower incisor, and two additional partial lower jaws. All the materials were encased within a single nodule.

Euprimates are characterized by a series of distinctive cranial traits, which includes a tendency for an enlarged brain, recession of the snout, convergence of the visual axes, and ossification of the orbital margins (Fleagle, 1999). Although diverse euprimate fossils are known from the very beginning of the Eocene, fossils that show unambiguous euprimate cranial morphology were previously unknown among the earliest euprimates. T. asiatica represents the earliest euprimate with the skull partially preserved; and it shows a definite euprimate skull morphology (Figure 1). The specimen also possesses the most complete known dentition of an early euprimate (Figure 2). The upper and lower tooth rows are preserved from canine to third molar. It has generally been hypothesized that the earliest euprimates have a dentition of 2.1.4.3/2.1.4.3 (Szalay and Delson, 1979; Fleagle, 1999). The new specimen confirms this hypothesis. T. asiatica shares the primitive dental characteristics of the other earliest euprimate members, and greatly resembles $T$. belgica. Some dental characteristics of $T$. asiatica, such as the relatively little reduced $\mathrm{P} 1 /$ and $\mathrm{P} / 1$, are even more primitive than the dentition in T. belgica.
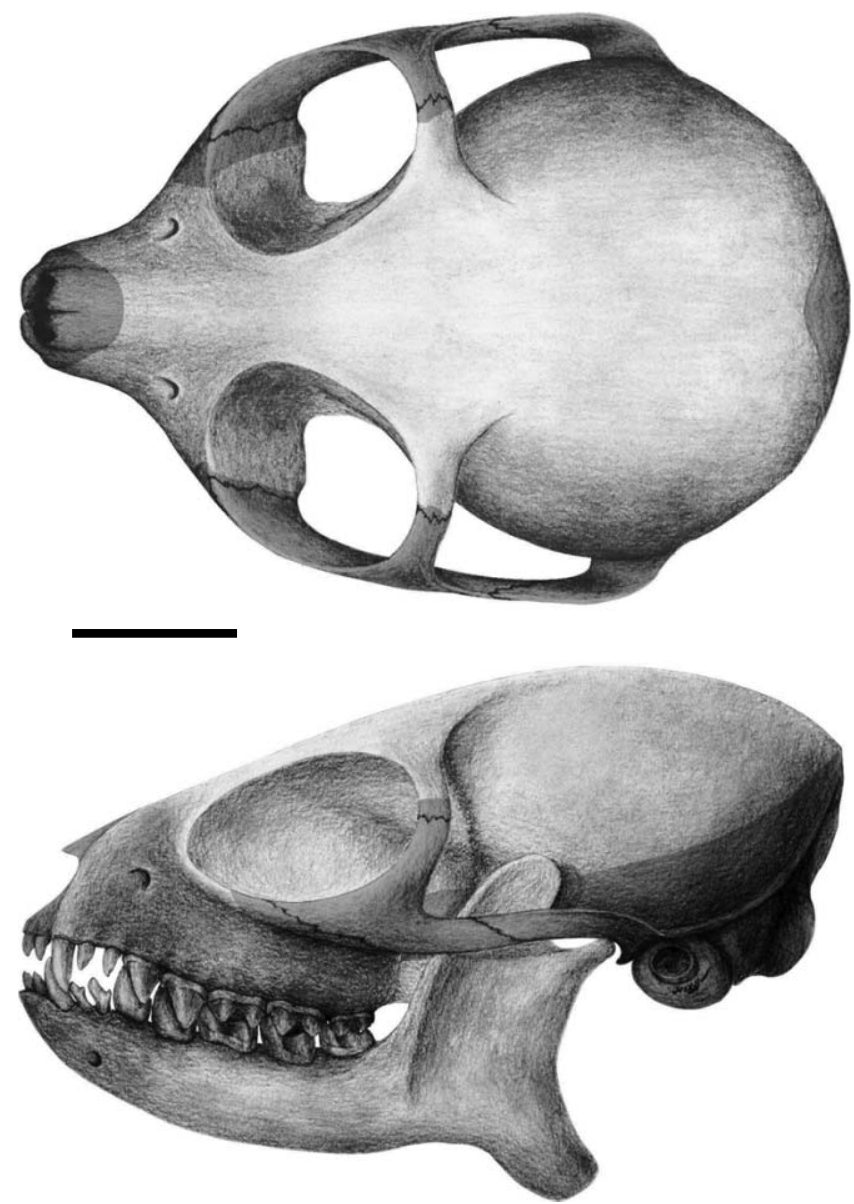

Figure 1. Reconstructed Teilhardina asiatica skull. Based on the specimen IVPP V12357. Dark shadow indicates the missing parts. Scale bar, $5 \mathrm{~mm}$. 


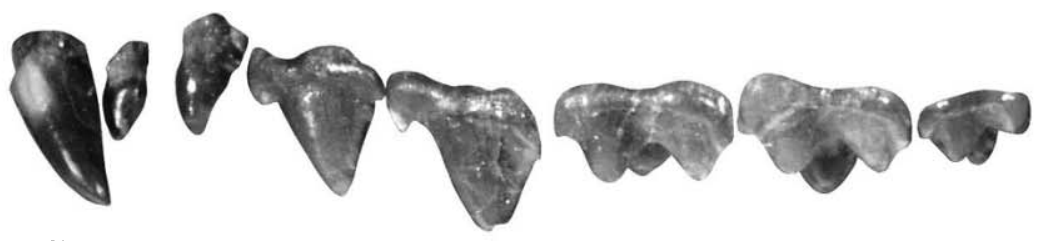

$a$
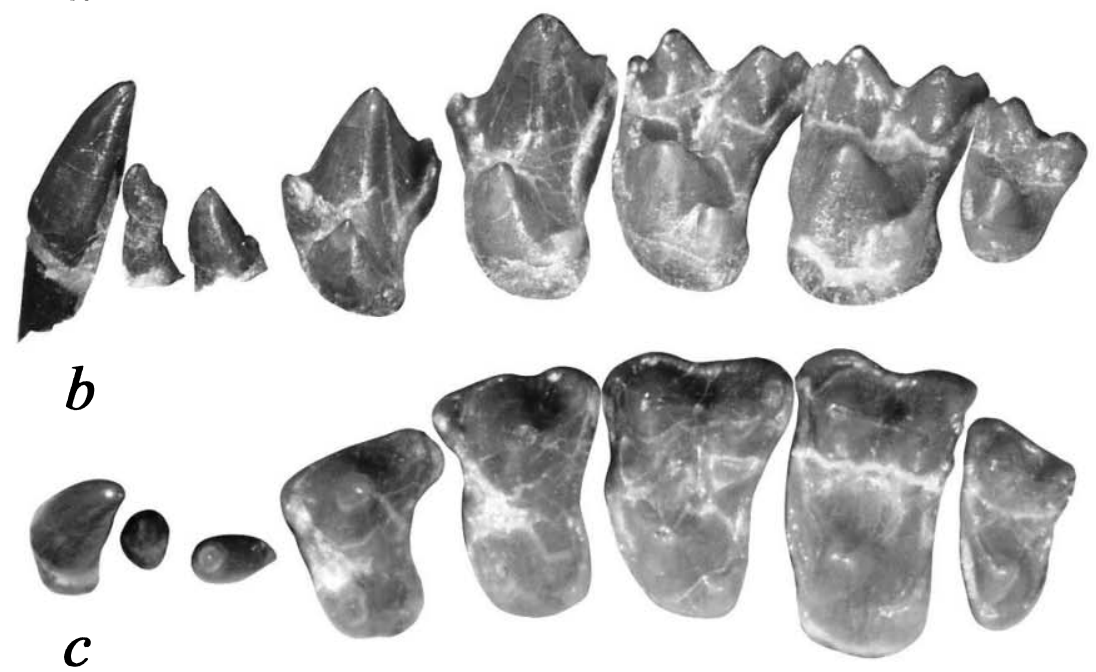

C
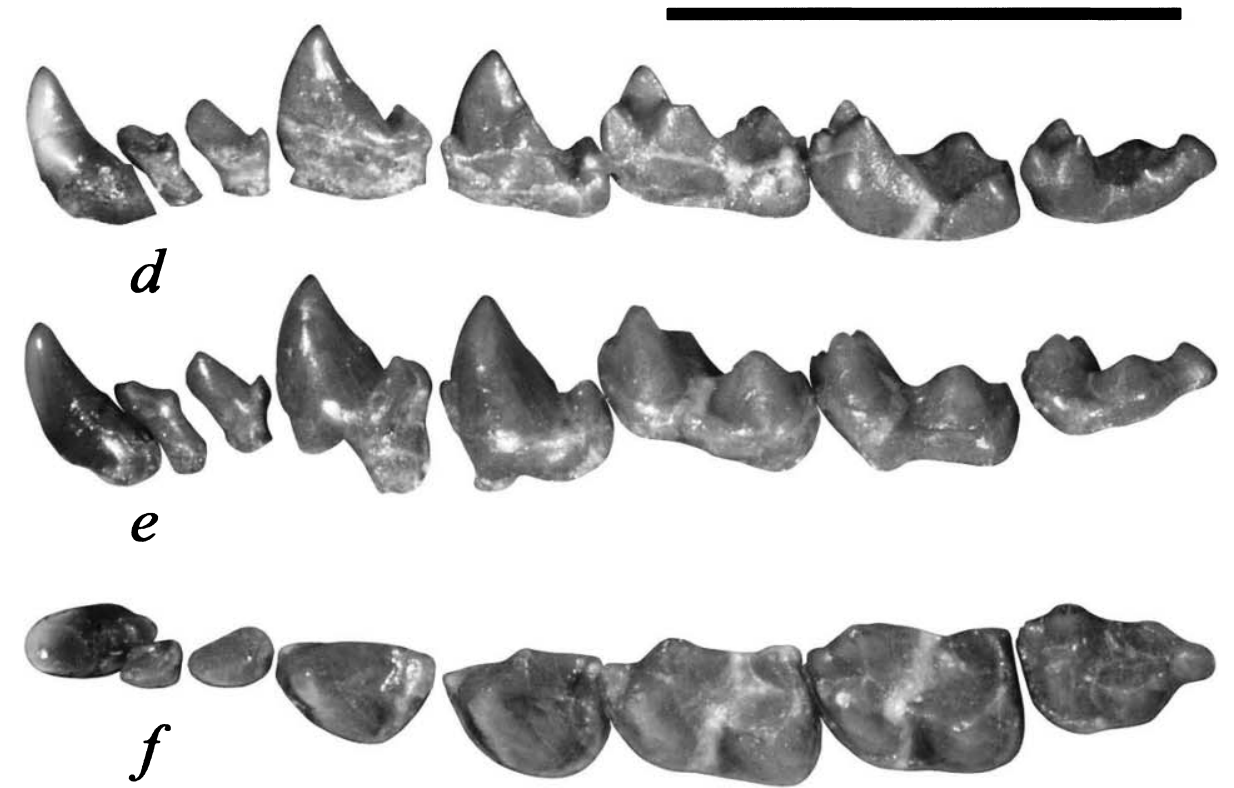

Figure 2. Dentition of Teilhardina asiatica (IVPP V12357) (from Ni et al., 2004). (a)-(c) Lateral, occlusolingual, and occlusal views of the left upper tooth row. (d)-(f) Reversed lingual, lateral, and occlusal views of the left lower tooth row. Scale bar, $5 \mathrm{~mm}$.

We recently undertook a cladistic analysis of $T$. asiatica (Figure 3) based on a modified dataset of Ross et al. (1998). T. asiatica forms a sister-group with the European species $T$. belgica. The two species constitute the basal taxa of the omomyid-tarsier-anthropoid clade, and lie very near the root of the primary division of euprimates. The North American species "Teilhardina" americana does not join with $T$. belgica and T. asiatica, but is polyphyletically related with the latter two species of Teilhardina. Indeed, cladistically,
"Teilhardina" americana is a basal taxon of the anaptomorphine-microchoerine clade. Further morphological comparison and systematic revision are needed to exclude the North American "Teilhardina" species from the genus.

\section{Euprimate Divergence and Asian Origins}

It is hypothesized that extant strepsirrhines and haplorhines can be traced back to the dichotomous subdivision 


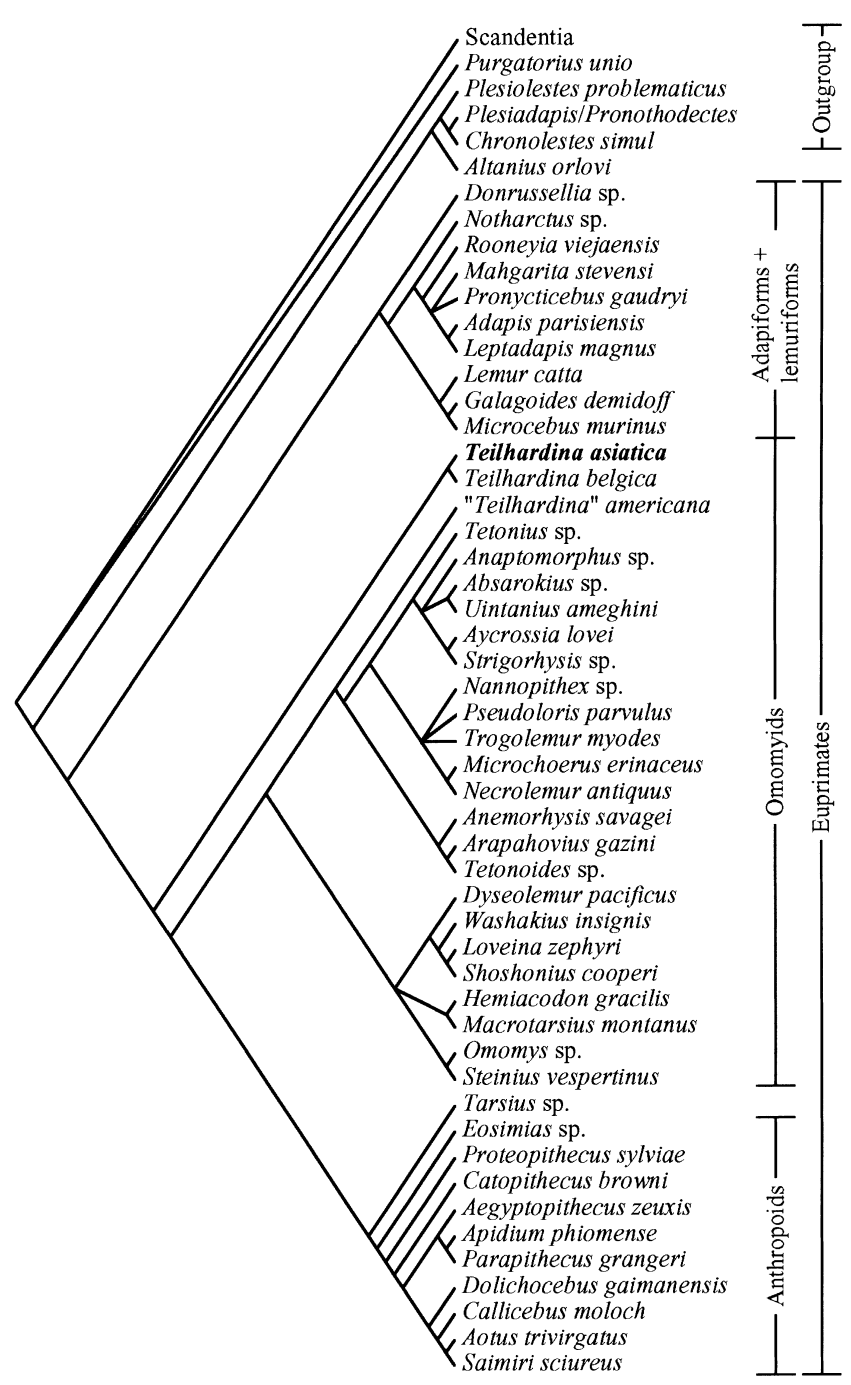

Figure 3. Strict consensus of 33 equally parsimonious trees (after $\mathrm{Ni}$ et al., 2004). Data are derived from the matrix published by Ross et al. (1998). In total 303 characters (194 dental, 49 cranial, 56 postcranial, and four soft tissue characters) and 52 taxa (five as outgroup) are included. All characters are equally weighted; partial character states are determined as ordered. A heuristic search was undertaken in PAUP $4.0 \mathrm{~b} 10$ (Swofford, 2000) with 5000 replications.

of basal euprimates (Kay et al., 1997; Ross et al., 1998). However, essential morphological differences between the two clades are scarce among the earliest euprimates. Because $T$. asiatica constitutes the most completely preserved early euprimate, it is natural to ask whether the new material will aid in clarifying the dichotomy at the times of their first appearance, or will narrow the morphological gap between the two. Our recent cladistic analysis supported the fundamental dichotomy within euprimates (Figure 3). T. asiatica does not obscure the strepsirrhine-haplorhine gap nor collapse the basal dichotomous structure of higher-level primate relationships. This strengthens the hypothesis of Kay, Ross, and colleagues (Kay et al., 1997; Ross et al., 1998) that basal diversification of euprimates was already established at the times of their first appearance in the earliest Eocene.
Based on molecular data, it has been postulated that euprimates separated from other placental mammals about 95 million years ago (Arnason et al., 1998). Recent statistical analysis of fossil data using new methodologies also predicts that the common ancestor of euprimates originated in the Cretaceous, approximately 81.5 million years ago (Tavaré et al., 2002), although alternative views exist (see Gingerich and Uhen, 1994). Fossil records of unambiguous euprimates, however, are known no earlier than from the earliest Eocene. The discovery of $T$. asiatica does not fill the time gap between the postulated origin and the earliest fossil record of euprimates, but it does furnish compelling evidence that primitive euprimates were already distributed throughout the holarctic zone from the very beginning of the Eocene. Our phylogenetic analysis further indicates that the division of the two main clades of euprimates had already diversified by that time. It is reasonable to consider that euprimates must have originated in the Paleocene at the latest.

The discovery of the most primitive omomyid euprimate in China strengthens the possibility of an Asian origin of the omomyid-tarsier-anthropoid clade. The Asian ancestor that may have been morphologically very similar to $T$. asiatica may have dispersed to Euro-America through three hypothesized routes. Through most of the Cenozoic, the North American landmass was connected with Northeast Asia by the Bering land bridge, and during the late Paleocene and early Eocene it was connected with Europe via the DeGeer and Thulean land bridges (McKenna, 1983a, b; Krause and Maas, 1990). It is possible that the early Asian omomyids dispersed to Europe through North America. It is also equally possible that the dispersal was initially from Asia to Europe, and then continued from Europe to North America. Either dispersal direction would predict that the early EuroAmerican omomyids, such as T. belgica and "Teilhardina" americana, are more closely related to each other than either is to T. asiatica. However, this prediction is not supported by our recent cladistic analysis (Figure 3 ). From this cladistic evidence, it appears more likely that a branch of omomyid deriving from the common Asian ancestor dispersed to North America through the Bering land bridge in the late Paleocene, or just before the beginning of the Eocene, and that this branch evolved into North American omomyids, including North American "Teilhardina" (Figure 4). Another branch, which retained quite a lot of primitive features and was morphologically very close to Chinese Teilhardina, might have developed near its center of origin and migrated to Europe when Asia was briefly connected with Europe at the Paleocene/Eocene boundary (Figure 4). Such a dispersal event would have resulted in the fossil evidence of T. belgica that suggests an Asian affinity of the genus.

During most of the Paleogene, Europe and western Asia were separated from northeastern Asia by the Turgai strait, which joined the Arctic and Tethys Sea. But paleogeographic models also postulate that for short periods in the late Paleocene and at the beginning of the Eocene the two landmasses were connected (Smith et al., 1994; Scotese, 2001). Research on the late Paleocene-early Eocene dinoflagellate cysts of the Turgai strait suggests that, during the intervals of major sea level fall of this period, important 


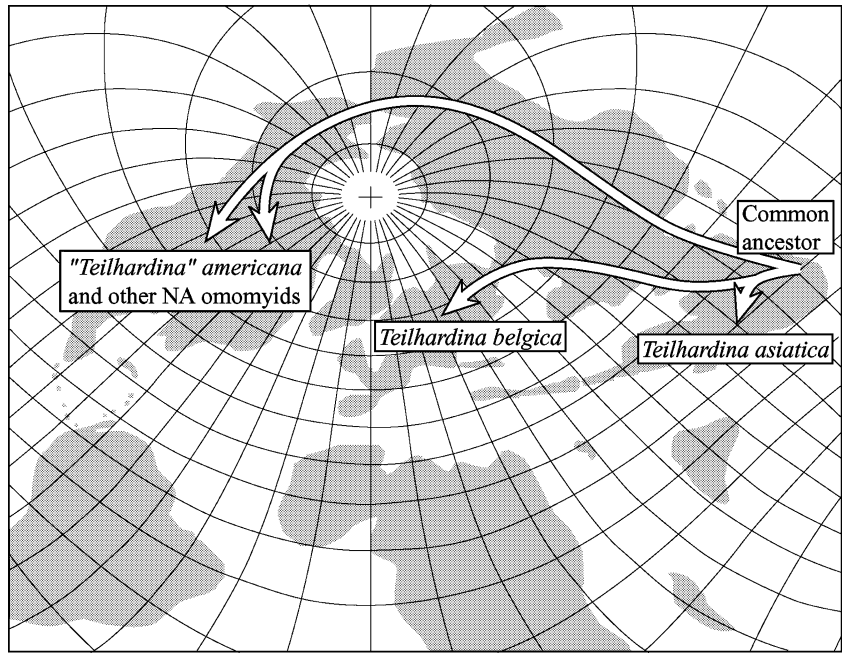

Figure 4. Suggested migration routes for early Asian omomyid dispersals to Europe and North America. A branch of omomyid derived from the common Asian ancestor dispersed to North America through the Bering land bridge in the late Paleocene or just before the beginning of the Eocene. Another branch, which is morphologically closer to Teilhardina asiatica, migrated to Europe when Asia was briefly connected with Europe at the Paleocene/Eocene boundary.

land connections for migrating terrestrial biota were formed (Iakovleva et al., 2001). The mammalian faunas of Europe and Asia had been almost completely isolated from each other during the Paleocene, but the faunal resemblance between the two continents abruptly increased in the early Eocene (Krause and Maas, 1990). Shared faunal elements between Europe and Asia in the early Eocene were interpreted as the result of direct faunal exchange across the Turgai strait (Savage and Russell, 1983; Hooker and Dashzeveg, 2003). T. belgica may have been an immigrant from Asia during this faunal exchange event at the beginning of the Eocene.

The question of where the common ancestor of euprimates first occurred is also controversial. It has been argued that a sudden appearance of omomyids and adapiforms in North America without precursors in Paleocene sediments suggests that both evolved elsewhere and dispersed into North America at the same time, and for a similar reason that euprimates could not have arisen in Europe (Gingerich, 1986, 1993; Rose, 1995). In fact, competing hypotheses suggested that euprimates might have arisen in Africa, the Indian subcontinent, or Asia (Gingerich, 1986; Szalay and Li, 1986; Krause and Maas, 1990; Rose, 1995; Rasmussen, 2002).

The African origin of euprimates is an old hypothesis (Walker, 1972; Gingerich, 1977, 1986). Recent explanations suggested that euprimates evolved in equatorial Africa during the late Paleocene and rapidly dispersed through Asia to reach North America and Europe when climates warmed globally across the Paleocene/Eocene boundary (Gingerich, 1990). Some discoveries of Eocene euprimates in northern Africa, such as Djebelemur martinezi and the questionable euprimate Altiatlasius koulchii, were taken as supporting evidence for such an idea (Gingerich, 1990; Sigé et al.,
1990; Hartenberger and Marandat, 1992). However, disagreement exists. Hooker et al. (1999) argued that "the presence of the toliapinid Altiatlasius in the African late Paleocene is judged to have resulted from dispersal from Europe and thus to have no bearing on primate centres of origin." The earliest euprimates from the northern continents, such as Cantius, Donrussellia, and Teilhardina, are all very primitive and closely related in morphology, indicating their derivation from a common ancestor. Based on this fact, we can infer that the morphology of their last common ancestor cannot be very different from these three taxa. $A$. koulchii, however, presents a very special morphological combination of apomorphies and plesiomorphies, and is very different from the earliest euprimates found in Europe, Asia, and North America. The earliest certain euprimate from Africa, D. martinezi, is of early Eocene age (Hartenberger and Marandat, 1992; Hartenberger et al., 1997), possibly late early Eocene or early middle Eocene (Godinot, 1994). In the other northern continents euprimates already existed at the very beginning of the Eocene. Most researchers believe that $D$. martinez $i$ shows a definitive affinity with adapiforms (Hartenberger and Marandat, 1992; Hartenberger et al., 1997; Simons, 1998; Fleagle, 1999; Gunnell and Miller, 2001), and it was regarded as an element involved in faunal exchange between Europe and northern Africa in the early Eocene (Hartenberger and Marandat, 1992). Thus, D. martinezi can hardly be regarded as a descendant of $A$. koulchii. To sum up, we argue that the recent discoveries from northern Africa do not serve as evidence for the African origin hypothesis.

The Indian subcontinent was also postulated as the center of origin of euprimates (Krause and Maas, 1990). This hypothesis supposed that the Indian subcontinent, carrying some basal placental mammals which immigrated from Africa via Madagascar in the late Cretaceous, traveled northeastward during the entire Paleocene. Evolution occurred in isolation when the landmass was drifting in the Indian Ocean. As the Indian subcontinent made harbor and began its collision with Asia, it possibly became the zoogeographic source for adapiforms, omomyids, and maybe also Artiodactyla, Perissodactyla, and Hyaenodontidae. Paleomagnetic and biostratigraphic data suggest that the collision between the Indian subcontinent and Asia began in the early Eocene (Allégre et al., 1984; Besse et al., 1984; Patriat and Achache, 1984; Robinson et al., 2000). However, the euprimate fossil record includes a holarctic distribution and basal diversification that already existed at the very beginning of the Eocene. Thus, the date of the India-Asia collision may not have occurred early enough for the known fossil euprimates to have originated from the Indian subcontinent.

On the assumption that Decoredon anhuiensis was an euprimate, Szalay and Li (1986) suggested that the sudden appearance of euprimates in the beginning of the Eocene in Euro-America was the result of a northern dispersal event rather than a northern migration of unknown Paleocene primate from African. As D. anhuiensis is now excluded from euprimates, the hypothesis of the Asian origin of euprimates received little support. However the discovery of $T$. asiatica, hitherto the earliest unequivocally identified euprimate from Asia, revives the hypothesis of an Asian origin for eupri- 
mates. Although T. asiatica is not older than other earliest euprimates found in Euro-America, the former is primitive within the known early euprimates. The possibility of finding morphologically more generalized euprimates (or protoeuprimates) in southern China is promising. Decoredon, Petrolemur, and Anaptogale from Paleocene deposits in southern China do have some molar features similar to primates, although they are not regarded as primates. Based on the premise that habitat preference is correlated with similarity in morphology, it might be supposed that a paleoenvironment suitable for Decoredon, Petrolemur, and Anaptogale might also be satisfactory for the ecological requirements of proto-euprimates in the Chinese Paleocene. A recent discovery from late Paleocene deposits in Anhui Province in southern China (which is under study by Dr Wang Yuanqing in Beijing) shows that morphologically euprimate-like placental mammals were quite diverse in the late Paleocene and early Eocene.

\section{Acknowledgments}

We would like to express our sincere thanks to Professor Nobuo Shigehara, Dr Masanaru Takai, Dr Hitomi Hongo, Dr Yutaka Kunimatsu, and Dr Michael A. Huffman for inviting the authors to participate in the international symposium "Asian Paleoprimatology: Evolution of the Tertiary Primates in Asia." We thank Mr Shuhua Xie for fossil preparation. We are grateful to Dr Jin Meng, Dr Masanaru Takai, Professor Richard F. Kay, Dr K. Christopher Beard, and Professor Gregg F. Gunnell for their helpful comments and suggestions. This research was funded by the National Natural Science Foundation of China, the Major Basic Research Project of Ministry of Sciences and Technology, China, and the Chinese Academy of Sciences.

\section{References}

Allégre C.J., Courtillot V., Tapponnier P., Hirn E., Mattauer M., Coulon C., Jaeger J.-J., Achache J., Schärer U., Marcoux J., Burg J.-P., Girardeau J., Armijo R., Gariépy C., Göpel C., Li T.D., Xiao X. C., Chang C.F., Li G.C., Lin B. Y., Teng J.W., Wang N.W., Chen G.M., Han T.L., Wang X.B., Deng W.M., Sheng H.B., Cao Y.G., Zhou J., Qiu H.R., Bao P.S., Wang S.C., Wang B.X., Zhou Y.X., and Xu R.H. (1984) Structure and evolution of the Himalaya-Tibet orogenic belt. Nature, 307: 17-22.

Arnason U., Gullberg A., and Janke A. (1998) Molecular timing of primate divergences as estimated by two nonprimate calibration points. Journal of Molecular Evolution, 47: 718-727.

Beard K.C. and Wang J. (1995) The first Asian plesiadapoids (Mammalia: Primatomorpha). Annals of Carnegie Museum, 64: $1-33$

Besse J., Courtillot V., Pozzi J.P., Westphal M., and Zhou Y.X. (1984) Palaeomagnetic estimates of crustal shortening in the Himalayan thrusts and Zango suture. Nature, 311: 621-626.

Bowen G.J., Clyde W.C., Koch P.L., Ting S., Alroy J., Tsubamoto T., Wang Y., and Wang Y. (2002) Mammalian dispersal at the Paleocene/Eocene boundary. Science, 295: 2062-2065.

Bown T.M. (1976) Affinities of Teilhardina (Primates, Omomyidae) with description of a new species from North America. Folia Primatologica, 25: 62-72.

Bown T.M. and Rose K.D. (1987) Patterns of dental evolution in early Eocene anaptomorphine primates (Omomyidae) from the Bighorn Basin, Wyoming. Journal of Paleontology, 61: 1162.

Dashzeveg D. and McKenna M.C. (1977) Tarsioid primate from the early Tertiary of the Mongolian People's Republic. Acta Palaeontologica Polonica, 22: 119-137.

Fleagle J.G. (1999) Primate Adaptation and Evolution. Academic Press, London.

Gingerich P.D. (1977) Radiation of Eocene Adapidae in Europe. Géobios, 1: 165-182.

Gingerich P.D. (1986) Early Eocene Cantius torresi - oldest primate of modern aspect from North America. Nature, 320: 319-321.

Gingerich P.D. (1990) African dawn for primates. Nature, 346: 411.

Gingerich P.D. (1993) Early Eocene Teilhardina brandti: oldest omomyid primate from North America. Contributions from the Museum of Paleontology, University of Michigan, Volume 28, pp. 321-326.

Gingerich P.D. and Uhen M.D. (1994) Time of origin of primates. Journal of Human Evolution, 27: 443-445.

Gingerich P.D., Dashzeveg D., and Russell D.E. (1991) Dentition and systematic relationships of Altanius orlovi (Mammalia, Primates) from the early Eocene of Mongolia. Géobios, 24: 637-646.

Godinot M. (1978) Un nouvel adapidé (primate) de l'éocène inférieur de Provence. Comptes Rendus Hebdomadaires des Séances de l'Académie des Sciences, Série D, 286: 18691872.

Godinot M. (1981) Les mammifères de Rians (éocène inférieur, Provence). Palaeovertebrata, 10: 43-126.

Godinot M. (1994) Early North African primates and their significance for the origin of Simiiformes (= Anthropoidea). In: Fleagle J.G. and Kay R.F. (eds.), Anthropoid Origins. Plenum Press, New York, pp. 235-295.

Godinot M., Crochet J.Y., Hartenberger J.L., Lange-Badré B., Russell D.E., and Sigé B. (1987) Nouvelles données sur les mammifères de Palette (Eocène inférieur, Provence). Münchner Geowissenschaftliche Abhandlungen, Reihe A, 10: 237288.

Gunnell G.F. and Miller E.R. (2001) Origin of Anthropoidea: dental evidence and recognition of early Anthropoids in the fossil record, with comments on the Asian Anthropoid radiation. American Journal of Physical Anthropology, 114: 177-191.

Hartenberger J.-L. and Marandat B. (1992) A new genus and species of an early Eocene primate from North Africa. Human Evolution, 7: 9-16.

Hartenberger J.-L., Crochet J.-Y., Martinez C., Feist M., Godinot M., Mannai Tayech B., Marandat B., and Sigé B. (1997) Le gisement de mammifères de Chambi (Éocène, Tunisie), dans son contexte géologique apport à la connaissance de l'évolution des mammifères en Afrique. In: Aguilar J.-P., Legendre S., and Michaux J. (eds.), Actes du Congrès BiochroM '97. Mémoires et Travaux de l'École Pratique des Hautes Études, l'Institut de Montpellier, 21: 263-274.

Hoffstetter R. (1977) Phylogénie des primates. Confrontations des résultats obtenus par les diverses voies d'approche $\mathrm{du}$ problème. Bulletins et mémoires de la Société d'anthropologie de Paris, Série 13, 4: 327-346.

Hooker J.J. and Dashzeveg D. (2003) Evidence for direct mammalian faunal interchange between Europe and Asia near the Paleocene-Eocene boundary. In: Wing S.L., Gingerich P.D., Schmitz B., and Thomas E. (eds.), Causes and Consequences of Globally Warm Climates in the Early Paleogene. Special Paper 369, Geological Society of America, Boulder, Colorado, pp. 479-500.

Hooker J.J., Russell D.E., and Phélizon A. (1999) A new family of Plesiadapiformes (Mammalia) from the old world lower Paleogene. Palaeontology, 42: 377-407.

Iakovleva A.I., Brinkhuis H., and Cavagnetto C. (2001) Late 
Palaeocene-Early Eocene dinoflagellate cysts from the Turgay Strait, Kazakhstan; correlations across ancient seaways. Palaeogeography, Palaeoclimatology, Palaeoecology, 172: 243-268.

Kay R.F., Ross C., and Williams B.A. (1997) Anthropoid origins. Science, 275: 797-804.

Krause D.W. and Maas M.C. (1990) The biogeographic origins of late Paleocene-early Eocene mammalian immigrants to the Western Interior of North America. In: Rose K.D. (ed.), Dawn of the Age of Mammals in the Northern Part of the Rocky Mountain Interior, North America. Special Paper 243, Geological Society of America, Boulder, Colorado, pp. 71-105.

McKenna M.C. (1983a) Holarctic landmass rearrangement, cosmic events, and Cenozoic terrestrial organisms. Missouri Botanical Gardens Annals, 70: 459-489.

McKenna M.C. (1983b) Cenozoic paleogeography of North Atlantic land bridges. In: Thiede J. (ed.), Structure and Development of the Greenland-Scotland Ridge. Plenum Press, New York, pp. 351-399.

Ni X., Wang Y., Hu Y., and Li C. (2004) A euprimate skull from the early Eocene of China. Nature, 427: 65-68.

Patriat P. and Achache J. (1984) India-Eurasia collision chronology has implications for crustal shortening and driving mechanism of plates. Nature, 311: 615-621.

Rasmussen D.T. (2002) The origin of primates. In: Hartwig W.C. (ed.), The Primate Fossil Record. Cambridge University Press, Cambridge, pp. 5-9.

Robinson J., Beck R., Gnos E., and Vincent R.K. (2000) New structural and stratigraphic insights for northwestern Pakistan from field and Landsat Thematic Mapper data. Geological Society of America Bulletin, 112: 364-374.

Rose K.D. (1995) The earliest primates. Evolutionary Anthropology, 3: 159-173.

Rose K.D. and Krause D.W. (1984) Affinities of the primate Altanius from the early tertiary of Mongolia. Journal of Mammology, 65: 721-726.

Rose K.D., Godinot M., and Bown T.M. (1994) The early radiation of euprimates and the initial diversification of Omomyidae. In: Fleagle J.G. and Kay R.F. (eds.), Anthropoid Origins. Plenum Press, New York, pp. 1-28.

Ross C., Williams B.A., and Kay R.F. (1998) Phylogenetic analysis of anthropoid relationships. Journal of Human Evolution, 35: $221-306$

Russell D.E. and Zhai R. (1987) The Paleogene of Asia: mammals and stratigraphy. Éditions du Muséum National d'Histoire Naturelle, Paris.

Russell D.E., Louis P., and Savage D.E. (1967) Primates of the French early Eocene. University of California Publications in the Geological Sciences, 73: 1-46.

Savage D.E. and Russell D.E. (1983) Mammalian Paleofaunas of the World. Addison-Wesley, Reading, Massachusetts.

Scotese C.R. (2001) Computer Animations on CD-ROM. PALEOMAP Project, Arlington, Texas.

Sigé B., Jaeger J.J., Sudre J., and Vianey-Liaud M. (1990) Altiatlasius koulchii $\mathrm{n}$. gen. et sp. primate omomyidé du Paléocène supérieur du Maroc, et les origines des euprimates. Palaeontographica Abteilung A, 214: 31-56.

Simons E.L. (1972) Primate Evolution: An Introduction to Man's Place in Nature. Macmillan, New York.

Simons E.L. (1998) The prosimian fauna of the Fayum Eocene/ Oligocene deposits of Egypt. Folia Primatologica, 69 (supplement 1): 286-294.

Simpson G.G. (1940) Studies on the earliest primates. Bulletin of the American Museum of Natural History, 77: 185-212.

Smith A.G., Smith D.G., and Funnell B.M. (1994) Atlas of Mesozoic and Cenozoic Coastlines. Cambridge University Press, Cambridge.

Swofford D.L. (2000) PAUP*. Phylogenetic Analysis Using Parsimony (*and Other Methods). Version 4. Sinauer Associates, Sunderland.

Szalay F.S. and Delson E. (1979) Evolutionary History of the Primates. Academic Press, London.

Szalay F.S. and Li C.-K. (1986) Middle Paleocene euprimate from Southern China and the distribution of primates in the Paleogene. Journal of Human Evolution, 15: 387-397.

Tavaré S., Marshall C.R., Will O., Soligo C., and Martin R.D. (2002) Using the fossil record to estimate the age of the last common ancestor of extant primates. Nature, 416: 726-729.

Teilhard de Chardin P. (1927) Les mammifères de l'Éocène inférieur de la Belgique. Memoires du Muséum Royal d'Histoire Naturelle de Belgique, 36: 1-33.

Ting S.-Y. (1993) A preliminary report on an early Eocene mammalian fauna from Hengdong, Hunan Province, China. Kaupia, 3: 201-207.

Walker A. (1972) The dissemination and segregation of early primates in relation to continental configuration. In: Miller J.A. (ed.), Calibration of Hominid Evolution. Scottish Academic Press, Edinburgh, pp. 195-218. 